\title{
Atmospheric emissions from vegetation fires in Portugal (1990-2008): estimates, uncertainty analysis, and sensitivity analysis
}

\author{
I. M. D. Rosa ${ }^{1, *}$, J. M. C. Pereira ${ }^{1}$, and S. Tarantola ${ }^{2}$ \\ ${ }^{1}$ Technical University of Lisbon, School of Agriculture, Center for Forest Studies, Tapada da Ajuda, \\ 1349-017 Lisboa, Portugal \\ ${ }^{2}$ Joint Research Centre of the European Commission, Ispra, Italy \\ *now at: Faculty of Natural Sciences, Division of Biology, Imperial College of London, Silwood Park Campus, UK
}

Received: 25 June 2010 - Published in Atmos. Chem. Phys. Discuss.: 22 September 2010

Revised: 31 January 2011 - Accepted: 10 March 2011 - Published: 21 March 2011

\begin{abstract}
Atmospheric emissions from wildfires in Portugal were estimated yearly over the period 1990-2008 using Landsat-based burnt area maps and land cover maps, national forest inventory data, biometric models, and literature review data. Emissions were calculated as the product of area burnt, biomass loading per unit area, combustion factor, and emission factor, using land cover specific values for all variables. Uncertainty associated with each input variable was quantified with a probability density function or a standard deviation value. Uncertainty and sensitivity analysis of estimates were performed with Monte Carlo and variance decomposition techniques. Area burnt varied almost 50-fold during the study period, from about 9000 ha in 2008 to 440000 ha in 2003. Emissions reach maximum and minimum in the same years, with carbon dioxide equivalent $\left(\mathrm{CO}_{2 \text { eq. }}\right)$ values of 159 and $5655 \mathrm{Gg}$ for 2008 and 2003, respectively. Emission factors, and the combustion factor for shrubs were identified as the variables with higher impact on model output variance. There is a very strong correlation between area burnt and emissions, allowing for good emissions estimates once area burnt is quantified. Pyrogenic emissions were compared against those from various economy sectors and found to represent $1 \%$ to $9 \%$ of the total.
\end{abstract}

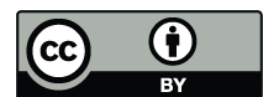

Correspondence to: I. M. D. Rosa (i.rosa09@imperial.ac.uk)

\section{Introduction}

Environmental impacts of wildfires affect abiotic and biotic ecosystem components, including flora, fauna, soil, water, air, and cultural resources (Brown and Smith, 2000). From the standpoint of atmospheric impacts, land use and natural resource managers need timely, accurate information to assess, monitor, and predict emission magnitudes and air quality impacts, namely from prescribed burning programs, acute health effects of smoke exposure, visibility reduction, and to assess tradeoffs between air quality impacts from wildland fire and prescribed fire (Sandberg et al., 2002).

Several studies have analysed various aspects of the atmospheric impacts of wildfires in Europe, ranging from the more general, such as air quality issues (Miranda et al., 2009a) and emissions assessment (Barbosa et al., 2009), to more specific or local, including particulate matter emissions, transport, and radiative effects (Hodzic et al., 2007), mercury emissions (Cinnirella and Pirrone, 2006), emissions and global warming relationships (Miranda et al., 1994), the impact of Eastern European agricultural fires on Arctic air pollution (Stohl et al., 2007), and satellite tracking of emission and transport of pollution from an extreme fire episode (Turquety et al., 2009). Barbosa et al. (2009) presented an analysis of wildfire numbers and area burnt in Europe using data from the European Forest Fire Information System (EFFIS), which show that an annual average (20002005) of about 95000 fires occurred and 600000 ha were burnt in 23 European countries. About two-thirds of the fires were recorded in five southern European countries (France, Greece, Italy, Portugal, and Spain) where an annual average of about 500000 burnt every year. Their pyrogenic carbon

Published by Copernicus Publications on behalf of the European Geosciences Union. 
dioxide $\left(\mathrm{CO}_{2}\right)$ annual emissions estimates for the 23 European countries were 8.4 to $20.4 \mathrm{Tg}_{\mathrm{year}}{ }^{-1}$.

A few studies have dealt with pyrogenic emissions in Portugal. Miranda et al. (1994) estimated $\mathrm{CO}_{2}$ emissions due to wildfires and found that in years when the burnt area exceeds 100000 ha this contribution could reach $7 \%$ of the total Portuguese $\mathrm{CO}_{2}$ emissions. Miranda et al. (2009a) modelled smoke plume impact on urban air quality in Lisbon during the extreme 2003 fire season and obtained results in reasonable agreement with those observed at ground-based monitoring networks. Miranda et al. (2009b) modeled air quality over the entire area of Portugal during August 2003, using an operational 3-D chemistry transport model. Results were compared with monitoring data from regional air quality networks, and were found to improve substantially where wildfire emissions were included, namely for particulate matter and ozone $\left(\mathrm{O}_{3}\right)$. Pio et al. (2008) collected aerosol samples in central coastal Portugal, also during the summer 2003 extreme fire season, when over 400000 ha of forests, shrublands and agricultural areas were burnt. During this period, aerosol samples were analysed for total mass and for a set of inorganic and organic compounds, including tracers of biomass burning. From organic C-to-levoglucosan or organic $\mathrm{C}$-to-K ratios it was estimated that 40 to $55 \%$ of primary organic $\mathrm{C}$ could be attributed to wood smoke. Studies by Silva et al. (2006) and Pio et al. (2006), which estimated pyrogenic emissions in Portugal during the 1990s, are direct precursors to the present analysis. Silva et al. (2006) estimated $\mathrm{CO}_{2}$ equivalent emissions ranging from a low of $0.474 \mathrm{Mt}$ in 1997 to a maximum of $3869 \mathrm{Mt} \mathrm{CO}_{2 \text { eq. }}$ in $1998 . \mathrm{CO}_{2 \text { eq. }}$ is a universal measurement to evaluate the impact of releasing different greenhouse gases to the atmosphere. Each greenhouse gas (GHG) has a global warming potential (GWP), which estimates the impact of a chemical species in global warming, when compared to the impact of $\mathrm{CO}_{2}$ (which has a GWP of 1). A linear regression model between annual area burnt and $\mathrm{CO}_{2 \text { eq. }}$ emissions for the 1990 s led to an estimate of $7.39 \mathrm{Mt}$ $\mathrm{CO}_{2 \text { eq. }}$ emitted during the record area burnt year 2003. They also calculated that the amount of GHG released by wildfires in 1991 corresponded to $22.4 \%$ of that emitted by the energy sector, $44.2 \%$ of the manufacturing and construction activities, $32.9 \%$ of the transport sector, $31.1 \%$ of that released by agriculture, and $81 \%$ of industrial activity emissions. Pio et al. (2006) estimated pyrogenic dioxin emissions as the second largest source for this pollutant at the national level (17\%).

Most biomass burning emission studies rely on the model developed by Seiler and Crutzen (1980), which combines information on above-ground biomass available for burning, combustion factors, burning area, and emission factors for a certain species and vegetation type, to calculate the pyrogenic emissions (Wooster et al., 2005). However, these variables are hard to estimate, which causes large uncertainties in results. Recently introduced methodologies based on satellite measurements, are meant to improve these estimates
(Wooster et al., 2004). Recent biomass burning studies both at regional (e.g. Pereira et al., 2009a) and global scales (e.g. Kaiser et al. 2009) rely on the relationship between fire radiative power (FRP), biomass consumed during a wildfire event, and smoke aerosol emission factor to provide estimates of the total amount of aerosol and trace gases emitted into the atmosphere (Woodster et al., 2005; Freeborn et al., 2008; Pereira et al., 2009a). These new methods are especially important to overcome one of the main limitations of traditional methods: the difficulty in obtaining near real-time emissions estimates. Despite their advantages, these new methodologies still have uncertainties attached. The FRP satellite products, both from the Moderate Resolution Imaging Spectroradiometer (MODIS) and from the Geostationary Operational Environmental Satellites (GOES), require complex validations, yet unavailable. In addition, they also suffer from technical problems such as channel saturation, undetected fires, and cloud cover, among others (Pereira et al., 2009a).

Schultz et al. (2008) considered that three main factors of uncertainty limit the accuracy of long-term, global biomass burning emission data sets. These factors, also relevant at the regional scale of the present study, are the accuracy of estimates of burnt area, combustion completeness, and emission factors. The effect of burnt area uncertainty on pyrogenic emission estimates was taken into account by Barbosa et al. (1999), and by Korontzi et al. (2004), using two different burnt area spatial datasets. Burnt area maps used herein were derived from much higher spatial resolution satellite imagery, and checked for accuracy against field data. Use of a country-wide, long-term, high accuracy burnt area geographical dataset is an important asset of the present study. From a methodological standpoint, another relevant contribution of this study is the use of a formal uncertainty and sensitivity assessment approach that is much more sophisticated than the error analysis approach used by Scholes et al. (1996), Levine (1996), and Barbosa et al. (1999).

The objectives of the present study are to estimate atmospheric emissions from wildfires in Portugal over the last two decades, to assess the uncertainty inherent in those estimates, and to identify the main sources of uncertainty. We rely on a combination of burnt area maps and land cover maps derived from remotely sensed data, forest inventory data, statistical growth models for forests and shrublands, and results from the literature for combustion factors, emissions factors, and for biomass of some land cover types.

\section{Study area}

Portugal is located between latitude $37^{\circ} \mathrm{N}$ and $42^{\circ} \mathrm{N}$ and between longitude $9.5^{\circ} \mathrm{W}$ and $6.5^{\circ} \mathrm{W}$. Climate is temperate, typically hot and dry during the summer, and cool and wet in winter. Topography is rugged, especially in the northern half of the country, and most vegetation cover is evergreen, drought resistant, and pyrophitic. These 
environmental features make the region susceptible to vegetation fires, a characteristic that has been reinforced during the last four or five decades by demographic, socio-economic (Mather and Pereira, 2006) and climatic trends (Pereira et al., 2002). Since the 1960 s many countryside areas have suffered substantial population losses, abandonment of agricultural fields, reduction of goat and sheep herds, resulting in a decrease in grazing, and lowered use of fuel wood. Thus, progressive accumulation of fine fuels has been occurring in forests and woodlands that previously were cleared of underbrush. Given the decrease in agricultural activity, large areas of marginal productivity were converted to forest or abandoned to old-field succession.

About one-third of the area of Portugal is covered by forests and woodlands. Maritime pine (Pinus pinaster) forests are located mainly in the northern half of the country, while Eucalypt (Eucalyptus globulus) forests are widespread in western Portugal, and in a few inland areas, in the central and southern parts of the country. Evergreen oak woodlands predominate in the south. Cork oak (Quercus suber) woodlands are the tree land cover type in SW Portugal and along the Tagus river valley, while Holm oak (Quercus rotundifolia) predominates in the SE. Agricultural areas occupy about half of the country and, although widespread, dominate in the central coastal plain, along main river valleys, and in the south. Central and northern Portugal agricultural landscapes are a mosaic of diverse crops, vineyards, and olive groves. Agriculture in southern Portugal is dominated by dry land farming of cereal crops. Most shrublands are located in northern and eastern Portugal, but also occur in other regions, usually mountainous and/or sparsely populated.

\section{Data and methods}

Calculation of GHG (carbon dioxide $\left(\mathrm{CO}_{2}\right)$, nitrous oxide $\left(\mathrm{N}_{2} \mathrm{O}\right)$, and methane $\left(\mathrm{CH}_{4}\right)$ ), other trace gases and aerosols pyrogenic emissions in Portugal between 1990 and 2008 relied on the model of Seiler and Crutzen (1980):

$E_{a}=\sum_{i} \sum_{n} A_{i} B_{n i} \alpha_{n i} E F_{a}$

where $E_{a}$ is the mass emitted of chemical species $a(\mathrm{~kg}), A_{i}$ is the burnt area on land cover class $i$ (ha), $B_{n i}$ is the biomass of the $n$ component on the land cover class $i\left(\mathrm{Mg} \mathrm{ha}^{-1}\right), \alpha$ is the combustion factor (\%), and $E F$ is the emission factor $\left(\mathrm{kg} \mathrm{Mg}^{-1}\right)$.

However, there are important uncertainties associated with estimates of these variables. Area burnt uncertainty is caused by large inter-annual variability and inaccuracies in satellitebased burnt area mapping. Uncertainties associated with biomass, combustion factors, and emissions factors are the result of sampling error and large variability in fire behaviour and effects on diverse vegetation types. Values for
Table 1. Land cover classes used to determine burnt area. These classes were aggregated into three main groups on the basis of methodological similarities for biomass estimation.

\begin{tabular}{ll}
\hline Land cover classes \\
\hline Forest & Maritime pine \\
& Umbrella pine \\
& Eucalypt \\
& Cork oak \\
& Holm oak \\
& Other Conifer \\
& Other Broadleaved \\
& Mixed (Maritime pine \\
& and Eucalypt) \\
& Mixed (Eucalypt and \\
& Cork oak) \\
\hline Agriculture & Agroforestry \\
& Orchard \\
& Vineyard \\
& Annual crops \\
& Olive groves \\
& Heterogeneous crops \\
& Sparsely vegetated \\
\hline Shrublands & Shrublands and grasslands \\
& Burnt more than once \\
\hline
\end{tabular}

* only for the 2000-2008 period

the variables in Eq. (1) were obtained from a combination of in-house data, literature review, and model-based estimates. We performed an uncertainty and sensitivity analysis to assess the dependence of $E_{a}$ on values of the input variables.

\subsection{Burnt area}

Burnt area in each land cover class and each year was estimated using the approach of Pereira and Santos (2003), which assumes that there are no land-use changes, apart from fire, during the period considered. Due to this assumption and the existence of different land cover datasets, with different spatial resolutions, the analysis was split into two periods: for the 1990s, we used a land cover map derived from aerial photo-interpretation, with a spatial resolution of 1:25000 and minimum mapping unit of 1 ha (Portuguese Geographic Institute, URL http://www.igeo.pt/produtos/CEGIG/COS.htm). From 2000 to 2008 , the analysis of annual fire incidence by land cover type relied on the CORINE2000 land cover map of Portugal, with a spatial resolution of 1:100000 and a minimum mapping unit of 25 ha (European Environment Agency, URL http://www.eea.europa.eu/data-and-maps/ figures/corine-land-cover-2000-by-country-1). We derived a common, simplified legend for the two maps, which was deemed adequate for estimating pyrogenic emissions 
(Table 1). The land cover maps for each analysis period were updated with the areas burnt annually, designated by the corresponding fire year.

The CORINE2000 land cover map legend only considers three main forest classes ("Broadleaved", "Conifer" and "Mixed"), which are too broad for emissions assessment, since each class contains forest types that are very different in structure, biomass, and vulnerability to fire. Therefore, we used data from the 2005-2006 National Forest Inventory (NFI) field plots to split these overly broad classes into homogeneous forest types, from the standpoint of emissions assessment.

The modified land cover map of Portugal was overlain with the fire perimeter atlas to quantify the area burnt annually in each land cover type. The fire perimeter atlas used in the present study is derived from Landsat satellite imagery for the period between 1990 and 2008, with a spatial resolution of $30 \mathrm{~m}$ and a minimum mapped unit of 5 ha (Pereira and Santos, 2003). The procedure is semi-automatic, starting with a supervised approach using classification trees, followed by on-screen editing of classification results. The final step - validation - is made by comparing the results against the Portuguese official field statistics (National Forest Authority, URL: http://www.afn.min-agricultura.pt/portal/dudf/ estatisticas) at the parish and county level.

\subsection{Biomass estimation}

Estimating biomass fuel loadings is complex due to the high spatial heterogeneity and dynamic character of vegetation. For the sake of simplicity, all land cover classes were aggregated into three main groups (Forests, Shrublands and Agriculture), on the basis of methodological similarities for biomass estimation (Table 1).

\subsubsection{Forests}

Forest fires can affect one or more fuel strata, including litter, surface fuels, and tree crowns. We considered four components of the total forest biomass: litter, understory shrubs, tree crown leaves and fine $(<2 \mathrm{~cm} \emptyset)$ branches. We assume that woody fuels $>2 \mathrm{~cm} \varnothing$ are not consumed by wildfires, which may underestimate emissions under extreme fire severity.

Forest litter fuel loadings were obtained from a literature review (Table 2). These values are from temperate ecosystems and are separated by different types of forest cover. The fact that only one study quantifies litter for Umbrella pine forests in the Mediterranean (Stamou et al., 1998), prevented us from including this variable in the uncertainty and sensitivity analysis.

NFI field plots provide data on understory shrub species composition, percent cover, and mean height. Equation (2) combines these data with species-specific bulk density (Silva et al., 2006), to yield understory shrub fuel loading per hectare:

$B_{j}=\sum_{1}^{6} \rho b_{\mathrm{s}} P c_{s i} A_{i}$

where $B_{j}$ represents the shrubs biomass in the plot $j$ $\left(\mathrm{kg} \mathrm{m}^{-2}\right), \rho b_{s}$ is the bulk density of shrubs species $\mathrm{s}$ $\left(\mathrm{kg} \mathrm{m}^{-3}\right), P c_{s i}$ is the percent cover species $s$ on height class $i(\%)$, and $A_{i}$ is the class height (m).

In order to determine the crown biomass we first had to estimate the trees' height, using hypsometric equations (National Forest Authority, 2010), since the NFI only describes the height of the dominant trees. Afterwards, we applied a set of equations from the Portuguese NFI (Correia et al., 2008 and National Forest Authority, 2010) to estimate the leaves biomass. For some species (Cork oak, Holm oak and other broadleaved) we used the equations from the Spanish NFI (Montero et al., 2005), since the Portuguese NFI does not provide leaf biomass equations for these species. Finally, to determine the fine branches biomass, we applied Spanish NFI equations (Montero et al., 2005), since the Portuguese NFI equations for branches biomass do not differentiate diameter classes.

\subsubsection{Shrublands}

This broad group includes the "Shrublands and grasslands" class, as well as those areas burnt at least twice during the period under analysis ("Burnt more than once"), and considers two components, namely litter and shrubs.

Estimation of total shrubland biomass relied on Olson's (1963) model and the field data gathered by Simões (2006), relating shrubland biomass and age. Olson's model is given by:

$W_{\mathrm{shb}}=a\left(1-e^{-b t}\right)$

where $W_{\text {shb }}$ is shrub biomass $\left(\mathrm{Mg} \mathrm{ha}^{-1}\right), a$ represents maximum fuel load $\left(\mathrm{Mg} \mathrm{ha}^{-1}\right)$ and $b$ is the time since last fire (years). Parameters $a$ and $b$ were estimated with an ordinary least squares model fit. Confidence intervals (95\%) of the parameters estimated mean value were calculated as well as the root mean square error of the model fitted, which quantifies the error associated to the predictions of shrub biomass.

Using Eq. (3) requires knowledge of the shrub patch age. We can determine age at the time of burning for the patches that burnt at least twice during the study period. However, we ignore the age of the "Shrublands and grasslands" patches at the time they burn during our study period. Therefore, it was necessary to estimate a mean patch age, for input into Olson's model. That was done using the methodology of Johnson and Gutsell (1994):

$\mathrm{APL}=b\left(\frac{\gamma\left(\frac{2}{c}\right)}{\gamma\left(\frac{1}{c}\right)}\right)$ 
Table 2. Litter load for different types of forest cover in Portugal.

\begin{tabular}{|c|c|c|}
\hline Forest cover & Litter load $\left(\mathrm{Mg} \mathrm{ha}^{-1}\right)$ & Reference \\
\hline \multirow[t]{8}{*}{ Maritime pine } & 10.3 & Cruz and Viegas (2001) \\
\hline & 5.1 to 32.1 & Fernandes et al. (2002) \\
\hline & 1.2 to 7.4 & Botelho et al. (1994) \\
\hline & 7.5 to 8.98 & Kavvadias et al. (2001) \\
\hline & 1.2 to 19.9 & Fernandes and Rigolot (2007) \\
\hline & 10.4 & van Wesemael and Veer (1992) \\
\hline & 1.7 to 13.3 & Viegas et al. (1998) \\
\hline & 1.36 to 7.36 & Fernandes (2009) \\
\hline Umbrella pine & 6.5 & Stamou et al. (1998) \\
\hline \multirow[t]{4}{*}{ Eucalypt } & 5.8 & Madeira et al. (2002) \\
\hline & 5.7 & Cruz and Viegas (2001) \\
\hline & 1.5 & Viegas et al. (1998) \\
\hline & 0.83 to 5.16 & Fernandes (2009) \\
\hline \multirow[t]{3}{*}{ Cork oak } & 5.57 & García et al. (2006) \\
\hline & 4.3 to 7.6 & Fernandes et al. (2000b) \\
\hline & 1.28 to 4.75 & Fernandes (2009) \\
\hline \multirow[t]{3}{*}{ Holm oak } & 5.57 & García et al. (2006) \\
\hline & 4.3 to 7.6 & Fernandes et al. (2000b) \\
\hline & 1.28 to 6.37 & Fernandes (2009) \\
\hline \multirow[t]{3}{*}{ Other Conifer } & 3.2 to 7.2 & Stamou et al. (1998) \\
\hline & 10.2 & Dimitrakopoulos (2002) \\
\hline & 13.79 to 16.38 & Kavvadias et al. (2001) \\
\hline \multirow[t]{4}{*}{ Other Broadleaved } & 4.3 to 5.1 & Fernandes et al. (2000b) \\
\hline & 5.4 to 7.5 & van Wesemael and Veer (1992) \\
\hline & 2.85 & Viegas et al. (1998) \\
\hline & 1.6 to 6.37 & Fernandes (2009) \\
\hline $\begin{array}{l}\text { Mixed forest } \\
\text { (Maritime pine and Eucalypt) }\end{array}$ & \multicolumn{2}{|c|}{ Mean value of the values obtained for each class individually } \\
\hline $\begin{array}{l}\text { Mixed forest } \\
\text { (Eucalypt and Cork oak) }\end{array}$ & \multicolumn{2}{|c|}{ Mean value of the values obtained for each class individually } \\
\hline
\end{tabular}

where APL represents the average prospective lifetime of a landscape patch (years), $b$ is the scale parameter of the Weibull function (years), $\gamma$ represents the gamma function (dimensionless) and $c$ is the shape parameter of the Weibull function (dimensionless). Parameters $b$ and $c$ parameters of the Weibull fire frequency distribution for Portugal were estimated by Oliveira (2010), using complete and incomplete intervals between fires.

Litter biomass was estimated using another model proposed by Olson (1963):

$X=\left(\frac{L}{k}\right)\left(1-e^{-k t}\right)$

where $X$ represents litter accumulation $\left(\mathrm{Mgha}^{-1}\right), L$ represents the annual litter production $\left(\mathrm{Mg} \mathrm{ha}^{-1}\right.$ year $\left.^{-1}\right), k$ is the decomposition rate $(\%)$ and $t$ is the vegetation's age (years). Assuming that $L$ depends on shrub leaf biomass, leaf/biomass ratio ( $\left.\mathrm{RW}_{\text {leaves }}\right)$ was previously estimated with Rambal's (2001) model:

$\mathrm{RW}_{\text {leaves }}=0.07+0.365 e^{-0.000589 W_{\text {shb }}}$

where $W_{\text {shb }}$ (here in $\mathrm{g} \mathrm{m}^{-2}$ ) is given by Eq. (3).

\subsubsection{Agriculture}

Wildfires affect a variety of agricultural crops, namely vineyards, olive groves, and rain fed cereal crops. However, no data are available on typical fuel loads for these land cover types, during the fire season. Therefore, we allocated standard BEHAVE fuel models (Anderson, 1982) to agricultural crops, according to the correspondence established by Vélez (2000) for Spain (Table 3). 
Table 3. Fuel models used to characterize fuel accumulation in the agriculture classes.

\begin{tabular}{lcccc}
\hline Agriculture classes & Fuel model & \multicolumn{3}{c}{ Fuel load $\left(\mathrm{Mg} \mathrm{ha}^{-1}\right)$} \\
\cline { 3 - 5 } & & $1 \mathrm{~h}$ & $10 \mathrm{~h}$ & Live \\
\hline $\begin{array}{l}\text { Orchard, Olive groves, Heterogeneous } \\
\text { crops and Sparsely vegetated }\end{array}$ & 1 & 1.6 & - & - \\
Agroforestry & 2 & & & \\
Annual crops & 3 & 4.5 & 2.2 & 1.1 \\
Vineyard & 5 & 6.7 & - & - \\
\hline
\end{tabular}

\subsection{Combustion factors}

The combustion factor represents the fraction of the total biomass that is consumed during a fire event. It is difficult to estimate, since it is influenced by vegetation factors such as age, phenology, and moisture content, and also by factors related to fire behaviour, namely fire line intensity, fire rate of spread, and flame residence time. Thus, combustion factors are often estimated from fuel consumption measurements in prescribed or experimental fires. However, these typically are less severe than wildfires, possibly leading to combustion factor underestimation.

Combustion factor values used in our analysis are primarily from temperate ecosystems and are separated by fuel strata. Discrimination by major land cover type is unfeasible, due to lack of data (Table 4). The data in Table 4 result from a review of the literature.

\subsection{Emission factors}

Emission factors represent the quantity of a chemical species that is released to the atmosphere per unit biomass burnt (Andreae, 1991). Andreae and Merlet (2001) compiled emission factors data from a wide range of regions and vegetation types, determined under natural conditions or in the laboratory. We used "Savanna and grassland" emissions factors for agricultural fires, since they affect mostly cereal crops and the herbaceous layer of other agricultural land cover types. "Extratropical forest" emissions factors were used for the forest and shrublands land cover classes. We calculated pyrogenic emissions of the following chemical species: carbon dioxide $\left(\mathrm{CO}_{2}\right)$, carbon monoxide $(\mathrm{CO})$, nitrous oxide $\left(\mathrm{N}_{2} \mathrm{O}\right)$, methane $\left(\mathrm{CH}_{4}\right)$, nitric oxide $\left(\mathrm{NO}_{\mathrm{x}}\right)$, total nonmethane hydrocarbons (TNMH), organic carbon (OC), black carbon (BC), total particulate matter (TPM) and particulate matter $<2.5 \mu$ m diameter $\left(\mathrm{PM}_{2.5}\right)$.

\subsection{Uncertainty and sensitivity analysis}

Model output variability was assessed through uncertainty analysis, followed by sensitivity analysis (Saltelli et al., 2004). Uncertainty analysis is based on a Monte Carlo approach. The first step in this procedure is to characterize the uncertainty associated with each input variable with a probability density function. Next, the variable space $(k=441)$ is sampled using quasi-random sequences (Sobol', 1967). In general, such sequences explore the input space better than simple random sampling strategies. Then, the model is evaluated $N(k+2)$ times, in order to subsequently estimate the sensitivity indices. Accuracy of the sensitivity estimates increase with $N$, which was set to 256 , for a total of 113408 model runs.

In the final step, sensitivity analysis is performed using a variance-based decomposition technique (Saltelli et al., 2009), to quantify the contribution of each variable to overall model output variability. The first order index $\left(S_{i}\right)$ represents the single effect of each variable on model output variance. The total order index $\left(S T_{i}\right)$ provides information on overall effect of a given input variable $X_{i}$, including all interactions with other variables; $S T_{i}$ is used to identify unimportant variables (Saltelli et al., 2004). These indices were determined for each year and for each variable, using the Saltelli and Jansen formulas (Saltelli et al., 2009). $S_{i}$ and $S T_{i}$, which are model independent, identify the key variables where uncertainty reduction efforts ought to focus. The quantity $1-\left(\sum \mathrm{S}_{i}\right)$ reveals the fraction of model output that is due to interactions among input variables. In addition, the difference $S T_{i}-S_{i}$ returns the extent to which the variable $X_{i}$ is involved in interactions with other variables; this information is very helpful for understanding the relationships between the input variables and the output at different points in time.

No systematically acquired ground truth data are available for a reliable accuracy assessment of the Landsat-based annual burnt area maps. Based on a comparison with countylevel field statistics, we postulated a coefficient of variation of $10 \%$ to quantify uncertainty for this variable.

In general, the Gamma, Weibull, and Exponential functions fitted well forest biomass (shrubs, leaves and fine branches) distributions, according to the $\chi^{2}$ goodness of fit test. When none of the statistical functions tested provided a good fit to the data, uncertainty was described by the discrete empirical distribution of the variable (Salvador et al., 2001). 
Table 4. Combustion factor for each biomass component.

\begin{tabular}{lll}
\hline Biomass component & Combustion factor (\%) & Reference \\
\hline Litter & 100 & Cinnirella et al. (2007) \\
59 to 92 & Ormeño et al. (2009) \\
90 to 100 & van der Werf et al. (2006) \\
93 & Stephens and Finney (2002) \\
50 to 70 & Arora and Boer (2005) \\
63 & Botelho et al. (1994) \\
47.6 to 86.7 & De Luis et al. (2004) \\
& 58.9 to 86.7 & Fernandes et al. (2000a) \\
\hline Shrubs & 60 & Cinnirella et al. (2007) \\
& 50 & Narayan et al. (2007) \\
& 83 & Botelho et al. (1994) \\
& 88.4 to 95.4 & Fernandes et al. (2000a) \\
& 16 to 100 & Fernandes et al. (1998) \\
\hline Leaves & 100 & Cinnirella et al. (2007) \\
& 80 to 100 & van der Werf et al. (2006) \\
& 70 to 80 & Arora and Boer (2005) \\
\hline Fine branches & 50 to 65 & Cinnirella et al. (2007) \\
\hline
\end{tabular}

Uncertainty in forest litter biomass data was described with the mean and standard deviation of the data, assuming a normal distribution; due to lack of sufficient data to attempt fitting a statistical distribution function.

Uncertainty in the distribution of standing biomass in shrublands was described with the mean and standard deviation of Olson's model predictions (Eq. 3), assuming a normal distribution. Rambal (2001) does not provide shrubland litter biomass model error information. Therefore, this variable was not included in the uncertainty and sensitivity analysis.

The standard BEHAVE fuel models used to represent the agricultural land cover types contain a single biomass loading value (Table 3 ). Therefore, emission and combustion factors are the only source of uncertainty for agricultural fires, in our analysis.

Uncertainty in combustion factors data was characterised by the mean and standard deviation of the data, assuming a normal distribution, because not enough data is available to fit statistical distributions. Finally, uncertainty in emission factors was represented with normal distributions, parameterised with the mean and standard deviation values given by Andreae and Merlet (2001).

\section{Results}

\subsection{Burnt area}

Inter-annual variability in area burnt was very high during the study period, ranging from over 300000 ha and over 400000 ha in 2005 and 2003, respectively, to a low of
9000 ha in 2008, i.e., over one order of magnitude (Fig. 1). Burnt area increased substantially, from a total of 900000 ha in the first decade to 1300000 ha in the second period.

During the 19 years under analysis, the land cover class most affected by fire was "Shrublands and grasslands", with more than 600000 ha burnt. Maritime pine forests and Eucalypt forests also burnt extensively: more than 335000 ha and 333000 ha, respectively. On the other hand, orchards and vineyards are the least fire-affected land cover types, with 3600 ha and 5300 ha burnt, respectively (Fig. 2). In Fig. 2, the class "Burnt more than once" includes those areas that burnt at least twice during each period. Due to lack of information we assume that these areas are left to abandonment after fire, which leads to fuel (shrubs and litter) accumulation.

These results confirm the small contribution of agricultural lands to the total area burnt and reinforce the idea that shrublands and forests are the most fire-affected areas. During the 1990 s shrublands contributed with $62 \%$ of the total area burnt (601 800 ha), forests with 30\% (295 450 ha) and agriculture with $8 \%$ (72910 ha). In the following period forests were the main contributor to total area burnt (54\%, 694374 ha) while shrublands contributed with $36 \%$ (463 $878 \mathrm{ha}$ ) and the agriculture with $10 \%$ (129803 ha). The breakdown by forest type of this increase in forest area burnt is shown in Fig. 2. Fire incidence is given by the ratio between the area burnt in a land cover class, and the total area of that class. 


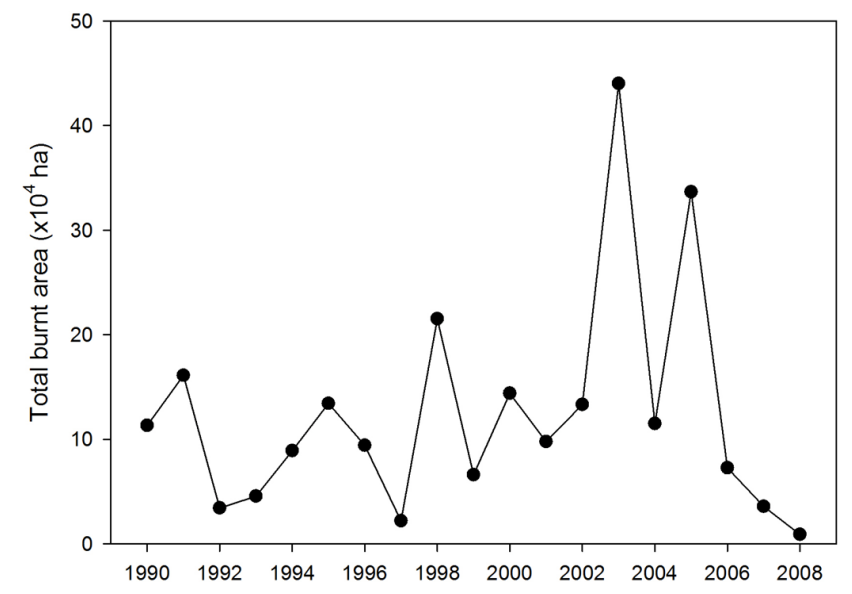

Fig. 1. Total burnt area in Portugal between 1990 and 2008.

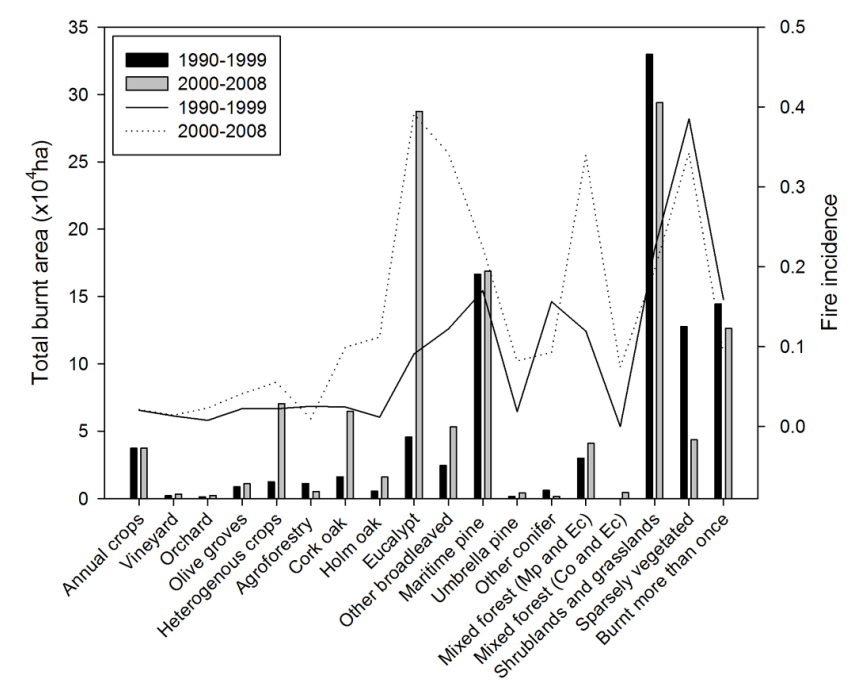

Fig. 2. Total burnt area and fire incidence by land cover class between 1990 and 2008.

\subsection{Biomass}

\subsubsection{Forests}

The median was used to quantify the biomass of shrubs, and of tree leaves and fine branches due to the strong bias of the data towards a higher frequency of low biomass values. Mean values are also given (in brackets) to facilitate comparison with results from previous research.

Forest understory shrub biomass displayed a wide range of values, varying from a median of 0 and $0.14 \mathrm{Mgha}^{-1}$ (1.8 and $3.09 \mathrm{Mg} \mathrm{ha}^{-1}$ ) for Holm oak and Cork oak in evergreen oak woodlands, to a maximum of $4.45 \mathrm{Mg} \mathrm{ha}^{-1}$ $\left(8.24 \mathrm{Mg} \mathrm{ha}^{-1}\right)$ in Maritime pine stands. Similar results were obtained for tree leaf and fine branch biomass. The lowest median tree leaf values were also obtained for evergreen oak woodlands, varying between $0.21 \mathrm{Mgha}^{-1}$

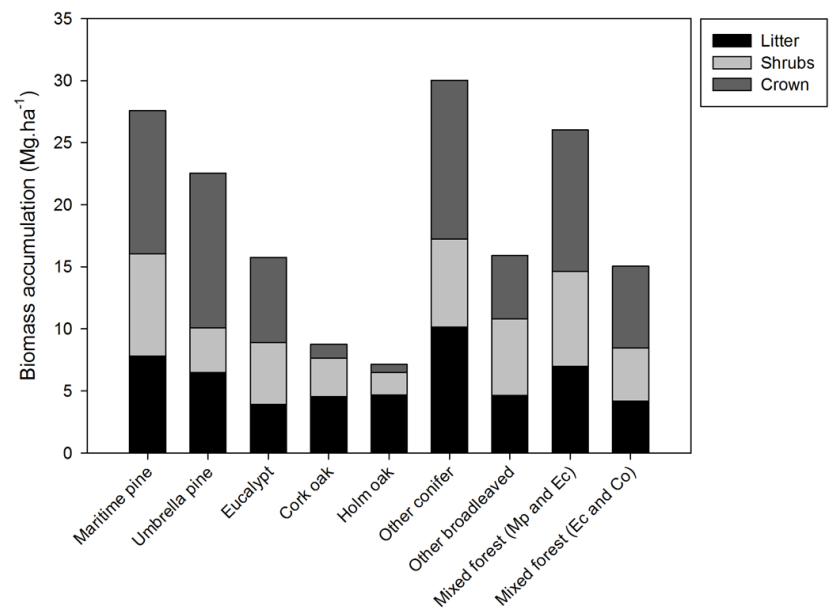

Fig. 3. Biomass accumulation $\left(\mathrm{Mg} \mathrm{ha}^{-1}\right)$ in each forest class.

and $0.32 \mathrm{Mg} \mathrm{ha}^{-1}\left(0.25\right.$ and $\left.0.41 \mathrm{Mgha}^{-1}\right)$ for Holm oak and Cork oak, respectively. For the fine branch biomass the values obtained for these woodlands were 0.35 and $0.54 \mathrm{Mgha}^{-1}\left(0.42\right.$ and $\left.0.7 \mathrm{Mgha}^{-1}\right)$ for Holm oak and Cork oak, respectively. The highest of all leaf median biomass values were obtained for "other conifer forests", with $4.74 \mathrm{Mgha}^{-1}\left(5.06 \mathrm{Mg} \mathrm{ha}^{-1}\right)$, while Umbrella pine forests displayed the highest median fine branch biomass, with $6.20 \mathrm{Mg} \mathrm{ha}^{-1}\left(7.61 \mathrm{Mg} \mathrm{ha}^{-1}\right)$.

Figure 3 shows mean biomass accumulation in each forest class, by biomass component. The difference in crown biomass values between the evergreen oaks and the other species is due to stand density differences. Evergreen oak woodlands in Portugal typically have very low tree density.

\subsubsection{Shrublands}

Parameter estimation for Olson's equation yielded the shrubland biomass accumulation model:

$W_{\text {shb }}=18.86\left(1-e^{-0.23 t}\right)$

where $W_{\mathrm{shb}}\left(\mathrm{Mgha}^{-1}\right)$ is the total aboveground shrub biomass and $t$ is the stand age, in years. The root mean square error of the model is $8 \mathrm{Mgha}^{-1}$, which is rather high, considering the mean biomass of the original data $\left(13 \mathrm{Mg} \mathrm{ha}^{-1}\right)$. Therefore, this variable will have a significant uncertainty attached. Table 5 shows the $95 \%$ confidence intervals for the model estimated parameters.

Mean patch age estimated for "Shrublands and grasslands" was 30 years, resulting in estimates of $3.40 \mathrm{Mg} \mathrm{ha}^{-1}$ and $18.84 \mathrm{Mgha}^{-1}$ for shrubland litter and aboveground biomass, respectively. The corresponding estimates for the areas that burnt at least twice during the period under analysis were $1.21 \mathrm{Mg} \mathrm{ha}^{-1}$ to $2.68 \mathrm{Mgha}^{-1}$ and $3.86 \mathrm{Mg} \mathrm{ha}^{-1}$ to $16.46 \mathrm{Mg} \mathrm{ha}^{-1}$ for shrub litter and aboveground biomass, respectively. 
Table 5. 95\% confidence interval of the parameters estimated mean value.

\begin{tabular}{crrr}
\hline Parameter & Mean & Lower limit & Upper limit \\
\hline$a$ & 18.86 & 17.12 & 20.60 \\
$b$ & 0.23 & 0.17 & 0.29 \\
\hline
\end{tabular}

\subsection{Uncertainty and sensitivity analysis}

For each year and each of the ten chemical species studied we obtained a frequency distribution of annual emissions as model output. As an example, Fig. 4 shows the model output for the $\mathrm{CO}_{2}$ emissions in 1990. Figure 5 shows the mean value and the upper and lower limit of the $95 \%$ confidence interval for six of these distributions $\left(\mathrm{CO}_{2}, \mathrm{CO}, \mathrm{N}_{2} \mathrm{O}, \mathrm{NO}_{\mathrm{x}}, \mathrm{CH}_{4}\right.$ and $\left.\mathrm{TNMH}\right)$. The remaining four distributions not shown in Fig. 5 ( $\mathrm{PM}_{2.5}$, TPM, OC and $\mathrm{BC}$ ) present the same emissions pattern, clearly linked to the annual variability in burnt area. For these four chemical species, emissions reached the maximum in 2003 (mean values of $4.11 \times 10^{7} \mathrm{~kg}, 5.57 \times 10^{7} \mathrm{~kg}, 3.64 \times 10^{7} \mathrm{~kg}$, and $1.80 \times 10^{6} \mathrm{~kg}$, respectively) and the minimum in 2008 (mean values of $0.11 \times 10^{7} \mathrm{~kg}, 0.16 \times 10^{7} \mathrm{~kg}, 0.10 \times 10^{7} \mathrm{~kg}$, and $0.05 \times 10^{6} \mathrm{~kg}$, respectively). Within the period under analysis $\mathrm{GHG}\left(\mathrm{CO}_{2}, \mathrm{CH}_{4}\right.$ and $\left.\mathrm{N}_{2} \mathrm{O}\right)$ emissions reach maximum in 2003 , with $5655 \mathrm{Gg} \mathrm{CO}_{2 \text { eq. }}$ and minimum in 2008 with $159 \mathrm{Gg} \mathrm{CO}_{2 \text { eq. }} . \mathrm{CO}_{2 \text { eq. }}$ estimates were obtained based on the GHG global warming potential $(\mathrm{GWP})$ of $\mathrm{CH}_{4}(\mathrm{GWP}=21)$ and $\mathrm{N}_{2} \mathrm{O}(\mathrm{GWP}=310)$.

All time series display a strong relation between mean and confidence interval, i.e. years with higher mean emissions values also show wider confidence intervals, implying higher uncertainty in the estimates. Direct proportionality between mean and confidence interval is expected in a model that is a sum of products. The standard deviation of the emission factor for the OC is higher than its mean value (Andreae and Merlet, 2001). Consequently, the uncertainty attached to the emissions of this chemical species is much higher than for any other.

In the sensitivity analysis we considered important those variables showing a first order sensitivity index equal or higher than $0.1\left(S_{i}>0.1\right)$. Figure 6 shows the results of the sensitivity analysis performed for the full time series and for four chemical species $\left(\mathrm{C}_{2} \mathrm{O}, \mathrm{CO}, \mathrm{N}_{2} \mathrm{O}\right.$ and $\left.\mathrm{CH}_{4}\right)$. Notice that a small number of factors (one to four) contribute to the majority of model output variance. For the remaining chemical species the results are very similar to those found for $\mathrm{CH}_{4}$. Only two variables (combustion factor of shrubs and emission factor) explained the majority (more than $80 \%$ ) of the output variance.

To understand the relationship between annual burnt area and GHG emissions, we established a linear regression

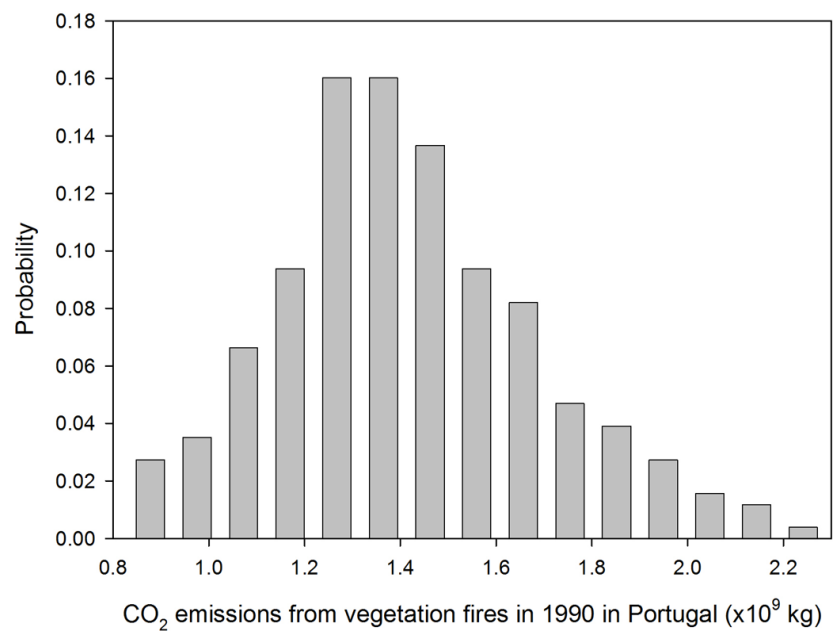

Fig. 4. Uncertainty analysis output for the $\mathrm{CO}_{2}$ emissions in 1990.

(Fig. 7) forced through the origin, since absence of burnt area must correspond to no pyrogenic emissions. In addition, to assess the uncertainty in the regression we used a bootstrap method (Effron, 1982). A sample of 1000 points was drawn to reconstruct the original curve and establish confidence intervals for the parameters (dashed lines in Fig. 7). The results revealed a slope distribution centred at $0.014( \pm 0.001$, significant at 0.05 level, by Student's $t$-test) and a coefficient of determination $\left(R^{2}\right)$ distribution highly skewed to high values $(0.95 \pm 0.03$, significant at 0.05 level, by Student's $t$-test $)$, which indicates a good agreement between annual burnt area and annual pyrogenic GHG emissions.

\section{Discussion}

\subsection{Burnt area}

Area burnt displays high inter-annual variability in Portugal. The two most severe fire years occurred in 2003 and 2005, which explains the substantially larger area burnt during the second study period (2000-2008). In spite of the large areas of forest (Maritime pine and Eucalypt) affected by fire during these two extreme years, over the full study period (19902008), shrublands and grasslands, which can be considered together with sparsely vegetated areas, clearly are the most fire-prone land cover class in Portugal. In part, this is due to the role fire plays in shrubland/grassland management for sheep and goat herding. These areas are frequently burnt, to promote the growth of new, palatable vegetation, and to prevent excessive shrub encroachment. Oliveira (2010) showed that the shortest fire return intervals in Portugal, calculated over the period 1975-2005, occur in regions with extensive shrublands, and peak in some mountainous areas under pastoral land use, which were observed to burn over 10 times in a 31-year period. The rationale for fire in sparsely vegetated 

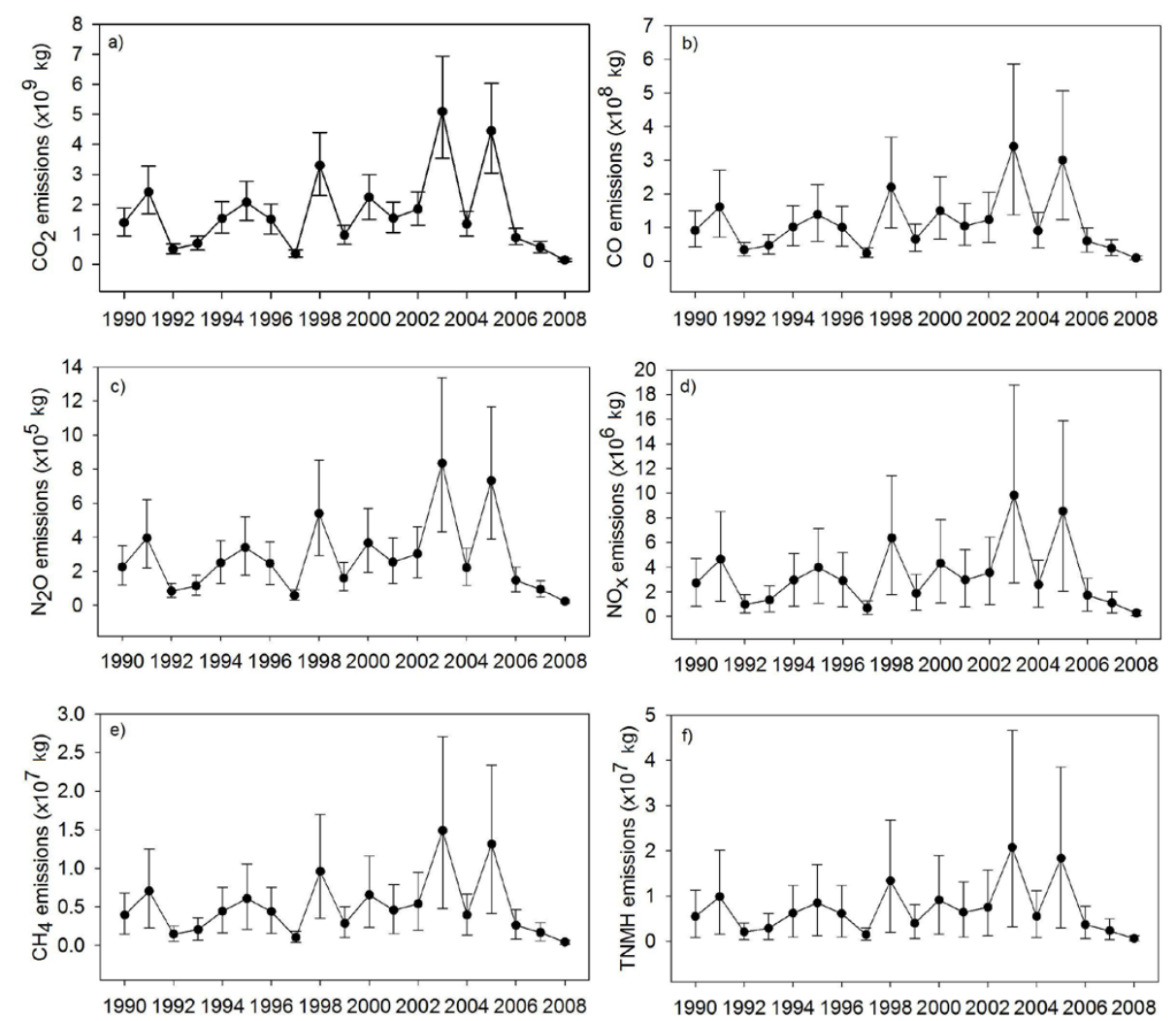

Fig. 5. Uncertainty analysis of (a) $\mathrm{CO}_{2}$, (b) $\mathrm{CO}$, (c) $\mathrm{N}_{2} \mathrm{O}$, (d) $\mathrm{NO}_{\mathrm{x}}$, between 1990 and 2008.

areas is similar to that of shrublands and grasslands and these two land cover classes taken together account for almost 800000 ha of area burnt.

A comparison of fire incidence between the two decades under analysis shows that fire incidence remained approximately constant in the agriculture and shrubland classes (Fig. 2). On the contrary, in some forest classes (e.g. Eucalypt) fire incidence increased greatly, contributing to the growth in forested area burnt during the second period. The expansion of area under Eucalypt plantation during the 1990s, and the effects of land abandonment in the Maritime pine forest region of central Portugal may help to explain the increase in forest area burnt.

\subsection{Forests biomass}

\subsubsection{Understory shrub biomass}

Our results revealed that the Maritime pine stands contain the highest shrub fuel loading, a consequence of decreased use of understory vegetation for cooking, heating, and fertilization of agricultural fields during the last half century. A relatively broad range of shrub biomass values has been reported for the understory of Maritime pine forests in Portu- gal. Fernandes and Rigolot (2007) estimated a mean value of $15 \mathrm{Mg} \mathrm{ha}^{-1}$, whereas Fernandes et al. (2002) provide a mean value of $6.1 \mathrm{Mg} \mathrm{ha}^{-1}$, varying from 0.1 to $20.8 \mathrm{Mg} \mathrm{ha}^{-1}$. Not only for the Maritime pine $\left(42 \mathrm{Mg} \mathrm{ha}^{-1}\right)$ but also for Eucalypt stands $\left(13.1 \mathrm{Mg} \mathrm{ha}^{-1}\right)$, the values obtained by Cruz and Viegas (2001) for total surface fuel (litter and shrubs) are higher than the ones we obtained $\left(8.24\right.$ and $4.96 \mathrm{Mgha}^{-1}$, respectively). However, they also obtained higher understory shrub fuel loadings for Maritime pine than for Eucalypt stands.

The higher understory shrub fuel loadings reported by Fernandes (2009) were found in Maritime pine forests $\left(0.9 \mathrm{Mg} \mathrm{ha}^{-1}\right.$ to $\left.6.35 \mathrm{Mg} \mathrm{ha}^{-1}\right)$ whereas Eucalypt forests and Cork oak woodlands recorded the lowest shrub biomass values $\left(0.49 \mathrm{Mg} \mathrm{ha}^{-1}\right.$ to $4.02 \mathrm{Mg} \mathrm{ha}^{-1} ; 0.56 \mathrm{Mg} \mathrm{ha}^{-1}$ to $4.39 \mathrm{Mg} \mathrm{ha}^{-1}$, respectively). Other broadleaved forests contained between $2.48 \mathrm{Mg} \mathrm{ha}^{-1}$ and $4.89 \mathrm{Mg} \mathrm{ha}^{-1}$. Our estimates are slightly higher than these, for all forests and woodlands.

Silva et al. (2006), whose methodology we followed to estimate forest understory shrub biomass, obtained qualitatively similar results using data from the 1995-1998 NFI. Mixed forests, other conifer forest and Maritime pine forest 

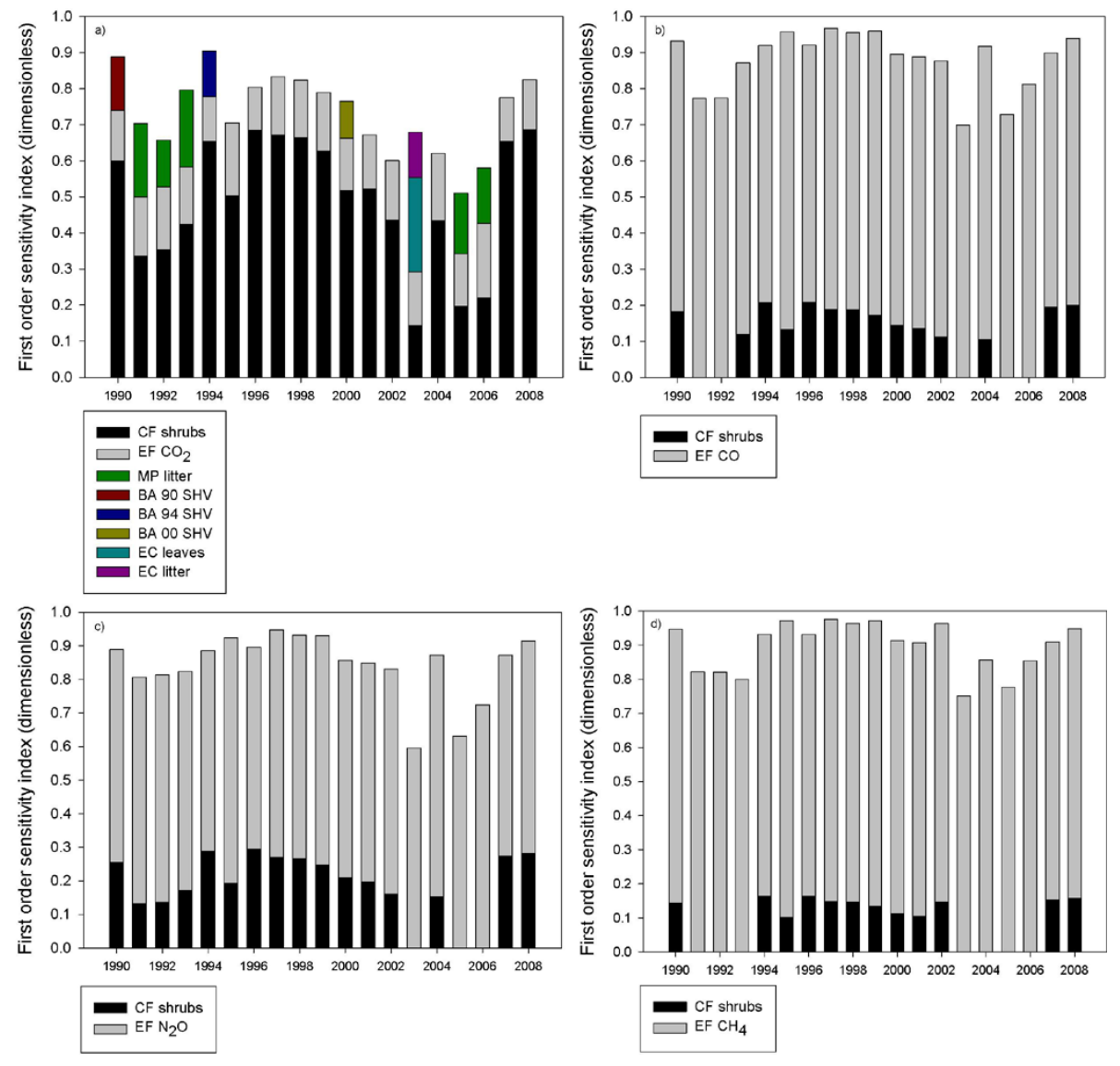

Fig. 6. Sensitivity analysis of (a) $\mathrm{CO}_{2}$, (b) $\mathrm{CO}$, (c) $\mathrm{N}_{2} \mathrm{O}$ and (d) $\mathrm{CH}_{4}$ emissions from vegetation fires in Portugal between 1990 and 2008 (CF - combustion factor; EF-emission factor; MP - Maritime pine; EC - Eucalypt; BA - Burnt area; SHV - Shrublands and grasslands class).

were the classes with higher loadings, whereas Holm oak and Cork oak woodlands and Eucalypt forest display the lowest loadings. We obtained generally lower estimates that those of Silva et al. (2006), possibly because we used data from the 2005-2006 NFI, which were collected shortly after the two worst fire years on record in Portugal (2003 and 2005).

\subsubsection{Leaf and fine branch biomass}

Maritime pine and Eucalypt forests have much higher leaf and fine branch biomass (11.53 $\mathrm{Mg} \mathrm{ha}^{-1}$ and $6.86 \mathrm{Mg} \mathrm{ha}^{-1}$ ) than Cork oak and Holm oak woodlands $\left(1.11 \mathrm{Mg} \mathrm{ha}^{-1}\right.$ and $0.67 \mathrm{Mg} \mathrm{ha}^{-1}$ ), mostly due to the much higher stand density of the former. Data on canopy biomass for forests and woodlands in Portugal are scarce. Fernandes et al. (2002) provide a range of values from $0.2 \mathrm{Mg} \mathrm{ha}^{-1}$ to $10.9 \mathrm{Mg} \mathrm{ha}^{-1}$ for Maritime pine forests in northern Portugal, while Fernandes and Rigolot (2007) obtained a mean value of $16 \mathrm{Mg} \mathrm{ha}^{-1}$ for the canopy biomass of Maritime pine stands.

At the national level, our canopy biomass estimates are slightly lower than those of Silva et al. (2006). The discrepancy is larger for Cork oak and Holm oak woodlands, probably reflecting differences in woodland density between
Portuguese evergreen oak woodlands and those considered in the European Environment Agency (1999) study that were used by Silva et al. (2006).

\subsection{Shrubland biomass}

\subsubsection{Shrub biomass}

Our estimates for the standing biomass of shrublands are within the range of values reported in the literature, both for the "Shrublands and grassland" class $\left(18.84 \mathrm{Mg} \mathrm{ha}^{-1}\right)$ and also for the areas that burnt at least twice (age known) in each study period (3.86 $\mathrm{Mg} \mathrm{ha}^{-1}$ and $16.46 \mathrm{Mg} \mathrm{ha}^{-1}$ ).

Vega et al. (2006) obtained higher results $\left(15 \mathrm{Mgha}^{-1}\right.$ to $\left.45 \mathrm{Mg} \mathrm{ha}^{-1}\right)$ than Viegas et al. (1998) $\left(10 \mathrm{Mg} \mathrm{ha}^{-1}\right.$ to $17 \mathrm{Mg} \mathrm{ha}^{-1}$ ) for the same shrub species (Erica sp., Ulex sp., Chamaespartium tridentatum). Fernandes et al. (1998) estimated shrub biomass for vegetation patches of various ages. For one year old patches, the value reported $\left(3.86 \mathrm{Mg} \mathrm{ha}^{-1}\right)$ is substantially higher than that we obtained from Eq. (7). However, our country-wide model includes data from areas with lower net primary productivity than that studied by Fernandes et al. (1998). Also, the biomass estimates 
obtained by Fernandes et al. (2000a) in the north-eastern Portugal for 5-year old shrublands are lower those predicted by Eq. (7). Our own estimates, although higher than those of Silva et al. (2006), are closer to values previously reported for Portugal.

\subsubsection{Litter biomass}

Our results for shrubland litter biomass are within the range of values reported for Mediterranean countries. Dimitrakopoulos (2002) estimated loadings of $0.7 \mathrm{Mgha}^{-1}$ to $3.4 \mathrm{Mg} \mathrm{ha}^{-1}$ for shrublands in Greece. In Turkey, Saglam et al. (2008) reported shrubland litter values of up to $12.4 \mathrm{Mgha}^{-1}$, with a mean value of $4.4 \mathrm{Mgha}^{-1}$. In Spain, De Luis et al. (2004) obtained higher values than ours, for 12-year old shrubland communities $\left(9.24 \mathrm{Mg} \mathrm{ha}^{-1}\right.$, $18.17 \mathrm{Mg} \mathrm{ha}^{-1}$, and $18.98 \mathrm{Mg} \mathrm{ha}^{-1}$ ). Our calculations of litter accumulation have a direct, deterministic relationship with shrubland biomass (Eq. 7). Since our estimates of shrubland biomass were higher than those of Silva et al. (2006), our litter estimates necessarily exceed theirs.

\subsection{Uncertainty and sensitivity analysis}

Figure 5 summarises model output uncertainty. Results of the uncertainty analysis for the entire time series reveal a very high inter-annual variability, which reflects annual area burnt. Within this large annual variability, 2003 was the year with the highest pyrogenic GHG and aerosols emissions. $\mathrm{CO}_{2}$ was the gas with larger quantities emitted $(5083 \pm 1,703 \mathrm{Gg}, 95 \%$ C.I., $n=256)$ (Fig. 5a). However, significant amounts of $\mathrm{N}_{2} \mathrm{O}$ and $\mathrm{CH}_{4}$ were also released $\left(259 \pm 140 \mathrm{Gg}\right.$ and $313 \pm 233 \mathrm{Gg} \mathrm{CO}_{2 \text { eq. }}, 95 \%$ C.I., $n=256$, respectively) (Fig. 5c and e). Pyrogenic emissions were lowest in 2008 with only $143 \pm 46 \mathrm{Gg} \mathrm{CO}_{2}, 9 \pm 6 \mathrm{Gg} \mathrm{CO}_{2 \text { eq. }}$. $\mathrm{CH}_{4}$ and $7 \pm 4 \mathrm{Gg} \mathrm{CO}_{2 \text { eq. }} \mathrm{N}_{2} \mathrm{O}$ (95\% C.I., $\left.n=256\right)$ emitted (Figs. 5a, c and e). Our estimates are highly correlated (Pearson's correlation $(r)$, all significant at 0.01 level) with the wildfires' GHG emissions reported by the European Environment Agency (EEA) for the same period in Portugal (Pereira et al., 2009b). The burnt area estimates are highly correlated $(r=0.95)$, as well as the GHG $(r=0.91), \mathrm{CO}_{2}(r=0.91)$, $\mathrm{CH}_{4}(r=0.99)$ and $\mathrm{N}_{2} \mathrm{O}$ emissions $(r=0.99)$.

Both methods revealed 2003 and 2008 as the years with higher and lower emissions, respectively. However, our estimates are much more conservative (5655 versus $11289 \mathrm{Gg} \mathrm{CO}_{2 \text { eq. }}$ in 2003), despite the fact that our burnt area estimates are higher (440 025 versus 286000 ha). These differences arise mainly from significant discrepancies between $\mathrm{CO}_{2}$ pyrogenic emissions estimates. Contrarily to our study, EEA also account for indirect carbon losses, such as the natural decay of dead organic matter following fires, as well as harvesting emissions, which account for the loss of the entire dead tree at the time of fire (Pereira et al., 2009b). This can lead to an overestimation since it includes leaves, branches, wood, bark and roots. On the contrary, as mentioned above, we assume that in a typical fire only leaves and small branches are consumed, which can lead to some underestimation in the case of severe wildfires.

The complexity of the sensitivity analysis performed in this study is due to the large number (a total of 441) of variables considered. However, most of these variables have $S_{i}$ and $S T_{i}$ values close to zero, meaning they have very small impact in the output variance and can be held constant. Interactions between variables play hardly any role in determining model output variability. Only a small number of factors interact $\left(S T_{i}>S_{i}\right)$, and they do it at a very weak levels. This is true for every chemical species except $\mathrm{CO}_{2}$, which displays stronger interactions between variables (Fig. 6a). $\mathrm{CO}_{2}$ emissions are orders of magnitude larger than those of other species, and since uncertainties are directly proportional to emissions (due to the multiplicative model used); this probably leads to the existence of more interactions between variables. The same argument can explain why in the years 2003 and 2005, which were the years with the highest amount of area burnt, there are more interactions than in any other year within the time series (Fig. 6). Therefore, the occurrence and magnitude of interactions are evidently related to the existence of variables with larger uncertainty range.

Sensitivity analysis for chemical species with a positive emission factor coefficient of variation (for example, $\mathrm{PM}_{2.5}$, $\mathrm{OC}$ and TNMH) revealed the large influence of this variable on model output. In these cases, the single effect of this variable always accounted for more than $80 \%$ of model output variance.

The sensitivity analysis identified emission factors for forests and shrublands, and the combustion factor of shrublands as the variables with the largest impact on model output variance. Importance of the latter variable possibly reflects the large extent of shrubland area burnt. The single effects of these two variables add to roughly $80-90 \%$ of the total model output variance, meaning that the effect of interactions between variables is quite low (10-20\% of the total variance). These results were similar for every year and every chemical species under analysis (except for $\mathrm{CO}_{2}$ ). Therefore, it is very important to reduce uncertainties attached to these variables, in order to lower model output variance.

Combustion factors intrinsically are very variable, due to their strong dependence on fuel moisture and fire behaviour. A shortage of data on this variable for wildfires in Portugal further enhances associated uncertainty. It may be possible to model combustion completeness as a function of a fire weather index (Amiro et al., 2001), thus obtaining more accurate estimates, but natural variability is expected to remain high. Emission factors proved to be the variable to which model outputs are most sensitive. Thus, it ought to be a priority target for uncertainty reduction in emissions estimation.

Miranda et al. (2008) published emission estimates for a range of land cover types in Portugal, but only mean values were provided. Pyrogenic emissions obtained in the present 


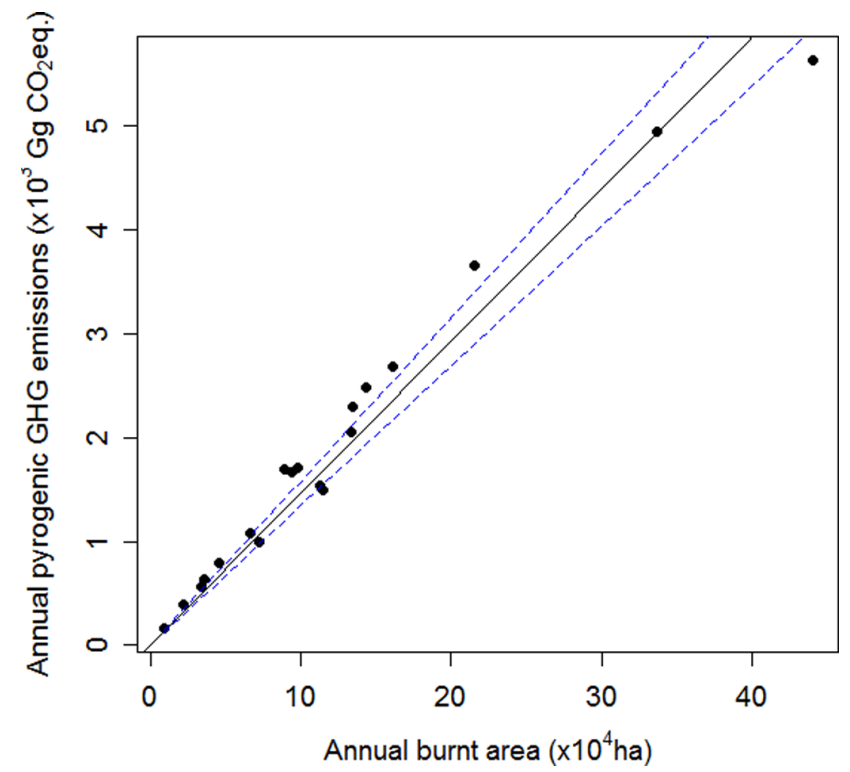

Fig. 7. Linear regression between the annual burnt area and the annual GHG pyrogenic emissions in Portugal between 1990 and 2008 (dashed lines represent the slope's 95\% confidence interval).

study are very similar to those provided by Silva et al. (2006) for the 1990s. For example, for 1990 Silva et al. (2006) estimated $1640 \mathrm{Gg} \mathrm{CO}_{2 \text { eq. }}$ of $\mathrm{GHG}$ whereas we determined a mean value of $1540 \mathrm{Gg} \mathrm{CO}_{2 \text { eq. }}$. For the $1990 \mathrm{~s}$, Silva et al. (2006) calculated a value of $19218 \mathrm{Gg} \mathrm{CO}_{2 \text { eq. }}$, whereas we obtained a value of $16360 \mathrm{Gg} \mathrm{CO}_{2 \text { eq. }}$. The difference is a result of the data variability included in our study.

As expected, Fig. 7 shows a high correlation (mean $R^{2}$ of 0.95 ) between the annual burnt area and the annual GHG pyrogenic emissions in Portugal, between 1990 and 2008. The regression slope represents the amount of GHG emitted per unit area. Thus, it is feasible to estimate annual pyrogenic emissions using area burnt as the single independent variable. Pio et al. (2006) used this approach to estimate dioxin emissions from wildfires in Portugal during 2003.

Finally, it is interesting to compare vegetation fire emissions in Portugal with those produced by other GHG sources (Fig. 8) (Pereira et al., 2009b). Energy production is the main source of GHG, representing 34 to $45 \%$ of total annual emissions, followed by transportation ( $25 \%$ to $35 \%)$. Industry and agriculture are also important sources of GHG, representing respectively about 10 to $15 \%$ and 12 to $20 \%$ of total annual emissions. Emissions from vegetation fires in Portugal represent 1 to $9 \%$ of the annual total.

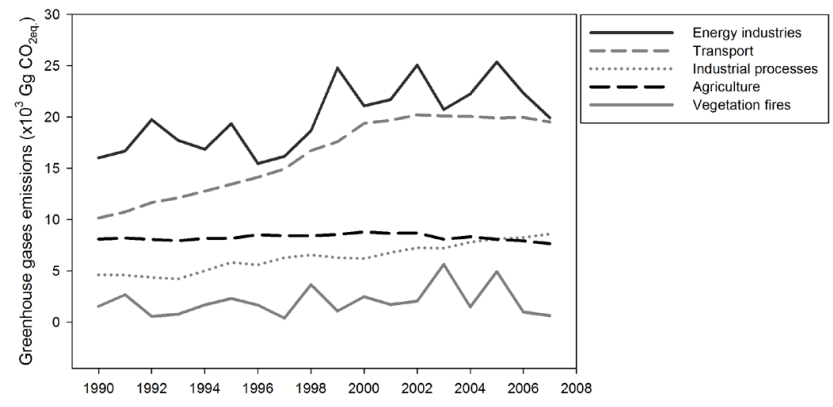

Fig. 8. Greenhouse gases emissions $\left(\mathrm{CO}_{2}, \mathrm{~N}_{2} \mathrm{O}\right.$ and $\left.\mathrm{CH}_{4}\right)$ from five different sources in Portugal, between 1990 and 2007.

\section{Conclusions}

We estimated national level, multi-year, pyrogenic emissions of greenhouse gases, other trace gases, and aerosols for Portugal, using the approach proposed by Seiler and Crutzen (1980). Our analysis relied on satellite-based burnt area maps and land cover maps, biomass field measurements and model-based estimates, and on previously published combustion completeness and emission factors data. Detailed uncertainty and sensitivity analysis established that emission factors and the combustion factor for shrublands and grasslands are the stronger determinants of uncertainty in emission estimates and, thus, ought to be the primary focus of future research efforts. It is feasible to estimate mean annual pyrogenic emissions as a function of area burnt, given the high correlation between the two variables. Within the extremely large variability found, 2003 and 2005 were the years with highest amount of area burnt and pyrogenic emissions. Of all ten chemical species studied, $\mathrm{CO}_{2}$ was the gas emitted in highest magnitude. However, other GHG, trace gases, and aerosols are also emitted in important quantities.

Unlike the other sources of GHG, pyrogenic emissions are strongly seasonal and heavily concentrated in the summer months. Thus, during peak fire activity periods their public health and environmental impacts can be much higher than might be inferred from the relatively low overall value. Additionally, while emissions from industry, agriculture, and transportation result in the production of goods and services, most pyrogenic emissions are associated with environmental and economic damages and losses.

Acknowledgements. We thank the two anonymous reviewers for their constructive and helpful suggestions on earlier drafts of this paper. J. M. C. Pereira participated under the scope of research project FUME - Forest fires under climate, social and economic changes in Europe, the Mediterranean and other fire-affected areas of the world, European Commission FP7-ENV-2009-, Grant Agreement Number 243888.

Edited by: A. Laaksonen 


\section{References}

Amiro, B. D., Todd, J. B., Wotton, B. M., Logan, K. A., Flannigan, M. D., Stocks, B. J., Mason, J. A., Martell, D. L., and Hirsch, K. G.: Direct carbon emissions from Canadian forest fires, 19591999, Can. J. Forest Res., 31(3), 512-525, 2001.

Anderson, H. E.: Aids to determining fuels models for estimating fire behavior, Gen. Tech. Rep. INT-122, USDA Forest Service, Intermountain Forest and Range Experiment Station, Ogden, UT, 22 p., 1982.

Andreae, M. O.: Biomass burning: its history, use, and distribution and its impacts on environmental quality and global climate, in: Global biomass burning. Atmospheric, climatic and biospheric implications, MIT Press, Cambridge, Massachusetts, 1-21, 1991.

Andreae, M. O. and Merlet, P.: Emission of trace gases and aerosols from biomass burning, Global Biogeochem. Cy., 15(4), 955-966, 2001.

Arora, V. K. and Boer, G. J.: Fire as an interactive component of dynamic vegetation models, J. Geophys. Res., 110, 1-20, 2005.

Barbosa, P. M., Stroppiana, D., Gregoire, J. M., and Pereira, J. M. C.: An assessment of vegetation fire in Africa (19811991): Burned areas, burned biomass, and atmospheric emissions, Global Biogeochem. Cy., 13, 933-950, 1999.

Barbosa, P., Camia, A., Kucera, J., Libertá, G., Palumbo, I., SanMiguel-Ayanz, J., and Schmuck, G.: Assessment of forest fire impacts and emissions in the European Union based on the European Forest Fire Information System, in: Developments in Environmental Science, edited by: Bytnerowicz, A., Arbaugh, M., Riebau, A., and Andersen, C., 8, 197-208, 2009.

Botelho, H. S., Vega, J. A., Fernandes, P. M., and Rego, F. M. C.: Prescribed fire behaviour and fuel consumption in northern Portugal and Galiza maritime pine stands, II International Conference on Forest Fire Research, Coimbra, Portugal, 21-24 November, 343-353, 1994.

Brown, J. K. and Smith, J. K.: Wildland fire in ecosystems: effects of fire on flora. Gen. Tech. Rep. RMRS-GTR-42-vol. 2, Ogden, UT: US Department of Agriculture, Forest Service, Rocky Mountain Research Station, 257 pp., 2000.

Cinnirella, S. and Pirrone, N.: Spatial and temporal distributions of mercury emissions from forest fires in Mediterranean region and Russian federation, Atmos. Environ., 40(38), 7346-7361, 2006.

Cinnirella, S., Pirrone, N., Allegrini, A., and Guglietta, D.: Modeling mercury emissions from forest fires in the Mediterranean region, Environ. Fluid Mech., 8(2), 129-145, 2007.

Correia, A., Faias, S., Tomé, M., Evangelista, M., Freire, J., and Carvalho, P.O.: Ajustamento simultâneo de equações de biomassa de Pinheiro Manso no Sul de Portugal, Silva Lusitana, 16(2), 197-205, 2008.

Cruz, M. G. and Viegas, D. X.: Caracterização do comportamento do fogo em complexos combustíveis comuns na região centro de Portugal, Silva Lusitana, 9(1), 13-34, 2001.

De Luis, M., Baeza, M., Raventos, J., and Gonzalez-Hidalgo, J.: Fuel characteristics and fire behaviour in mature Mediterranean gorse shrublands, Int. J. Wildland Fire, 13(1), 79-87, 2004.

Dimitrakopoulos, A. P.: Mediterranean fuel models and potential fire behaviour in Greece, Int. J. Wildland Fire, 11, 127-130, 2002.

Efron, B.: The Jackknife, the Bootstrap, and Other Resampling Plans, Society of Industrial and Applied Mathematics CBMS-
NSF Monographs, 38, 100 pp., 1982.

European Environment Agency: EMEP/CORINAIR Emission Inventory Guidebook, 3rd edn., Technical report N30, Other sources and sinks, Group 11, 1999.

Fernandes, P. M.: Combining forest structure data and fuel modelling to assess fire hazard in Portugal, Ann. For. Sci., 66(4), 415,1-415,9, 2009.

Fernandes, P. M. and Rigolot, E.: The fire ecology and management of maritime pine (Pinus pinaster Ait.), Forest Ecol. Manag., 241(1-3), 1-13, 2007.

Fernandes, P. M., Ribeiro, L., Botelho, H., and Rodrigues, A.: Short-term recovery of Erica australis shrubland in NE Portugal after prescribed burning, III International Conference on Forest Fire Research, 14th Conference on Fire and Forest Meteorology, Luso, 16-20 November, 1853-1862, 1998.

Fernandes, P. M., Catchpole, W. R., and Rego, F. C.: Shrubland fire behaviour modelling with microplot data, Can. J. Forest Res., 30, 889-899, 2000a.

Fernandes, P. M., Ruivo, L., Goncalves, P., Rego, F., and Silveira, S.: Dinâmica da combustibilidade nas comunidades vegetais da Reserva Natural da Serra da Malcata, Actas do Congresso Ibérico de Fogos Florestais, Castelo Branco, Portugal, 2000 b.

Fernandes, P. M., Loureiro, C., Botelho, H., Ferreira, A., and Fernandes, M.: Avaliação indirecta da carga de combustível em pinhal bravo, Silva Lusitana, 10(1), 73-90, 2002.

Freeborn, P. H., Wooster, M. J., Hao, W. M., Ryan, C. A., Nordgren, B. L., Baker, S. P., and Ichoku, C.: Relationships between energy release, fuel mass loss, and trace gas and aerosol emissions during laboratory biomass fires, J. Geophys. Res., 113, D01301, doi:10.1029/2007JD008679, 2008.

García, L., Maltez-Mouro, S., Perez-Ramos, I., Freitas, H., and Maranon, T.: Counteracting gradients of light and soil nutrients in the understory of Mediterranean oak forests, Web Ecology, 6, 67-74, 2006.

Hodzic, A., Madronich, S., Bohn, B., Massie, S., Menut, L., and Wiedinmyer, C.: Wildfire particulate matter in Europe during summer 2003: meso-scale modeling of smoke emissions, transport and radiative effects, Atmos. Chem. Phys., 7, 4043-4064, doi:10.5194/acp-7-4043-2007, 2007.

Johnson, E. A. and Gutsell, S. L.: Fire frequency models, methods and interpretations, Adv. Ecol. Res., 25, 239-287, 1994.

Kaiser, J. W., Flemming, J., Schultz, M. G., Suttie, M., and Wooster, M. J.: The MACC Global Fire Assimilation System: First Emission Products (GFASv0), ECMWF Technical Memorandum 596, $1-17,2009$.

Kavvadias, V., Alifragis, D., Tsiontsis, A., Brofas, G., and Stamatelos, G.: Litterfall, litter accumulation and litter decomposition rates in four forest ecosystems in northern Greece, Forest Ecol. Manag., 144(1-3), 113-127, 2001.

Korontzi, S., Roy, D. P., Justice, C. O., and Ward, D. E.: Modeling and sensitivity analysis of fire emissions in southern Africa during SAFARI 2000, Remote Sens. Environ, 92(2), 255-275, 2004.

Levine, J. S.: Introduction, in: Biomass Burning and Global Change, Remote Sensing, Modeling and Inventory Development, and Biomass Burning in Africa, edited by: Levine, J. S., MIT Press, Cambridge, Massachusetts, 1, xxxv-xliii, 1996.

Madeira, M., Fabião, A., Pereira, J. S., Araújo, M., and Ribeiro, C.: Changes in carbon stocks in Eucalyptus globulus Labill, 
plantations induced by different water and nutrient availability, Forest Ecol. Manag., 171(1), 75-85, 2002.

Mather, A. and Pereira, J. M. C.: Transição florestal e fogo em Portugal, in: Incêndios florestais em Portugal: caracterização, impactes e prevenção, edited by: Pereira, J. S., Pereira, J. M. C., Rego, F., Silva, J. M. N., and Silva, T. P., ISAPress, Lisboa, 257-282, 2006.

Miranda, A. I., Coutinho, M., and Borrego, C.: Forest fire emissions in Portugal: A contribution to global warming?, Environ. Pollut., 83(1-2), 121-123, 1994.

Miranda, A. I., Monteiro, A., Martins, V., Carvalho, A., Schaap, M., Builtjes, P., and Borrego, C.: Forest fires impact on air quality over Portugal, in: NATO/CCMS International Technical Meeting on Air Pollution Modeling and its applications, 29, 190-198, edited by: Borrego, C. and Miranda, A. I., Springer, Aveiro, Portugal, 2008.

Miranda, A. I., Marchi, E., Ferretti, M., and Millán, M. M.: Forest fires and air quality issues in Southern Europe, in: Developments in Environmental Science, edited by: Bytnerowicz, A., Arbaugh, M., Riebau, A., and Andersen, C., 8, 209-231, 2009a.

Miranda, A. I., Borrego, C., Martins, H., Martins, V., Amorim, J. H., Valente, J., and Carvalho, A.: Forest fire emissions and air pollution in southern Europe, 171-187, in: Earth observation of wildland fires in Mediterranean ecosystems, edited by: Chuvieco, E., Springer-Verlag, Berlin, Heidelberg, Germany, $2009 \mathrm{~b}$.

Montero, G., Ruiz-Peinado, R., and Munoz, M.: Producción de biomasa y fijación de $\mathrm{CO}_{2}$ por los bosques espanoles, INIA, 220, 25-36, 2005.

Narayan, C., Fernandes, P. M., van Brusselen, J., and Schuck, A.: Potential for $\mathrm{CO}_{2}$ emissions mitigation in Europe through prescribed burning in the context of the Kyoto Protocol, Forest Ecol. Manag., 251(3), 164-173, 2007.

National Forest Authority: 5th National Forest Inventory Mainland Portugal, http://www.afn.min-agricultura.pt/portal/ifn/ relatorio-final-ifn5-florestat-1, 2010.

Oliveira, S. L. J., Pereira, J. M. C., and Carreiras, J. M. B.: Fire frequency analysis in Portugal (1975-2005), using satellite-based burned area maps, Int. J. Wildland Fire, submitted, 2010.

Olson, J. S.: Energy storage and the balance of producers and decomposers in ecological systems, Ecology, 44(2), 322-331, 1963.

Ormeño, E., Céspedes, B., Sánchez, I., Velasco-García, A., Moreno, J., Fernandez, C., and Baldy, V.: The relationship between terpenes and flammability of leaf litter, Forest Ecol. Manag., 257(2), 471-482, 2009.

Pereira, J. S., Correia, A. V., Correia, A. P., Pereira, J. M. C., Oliveira, A. C., Freitas, H., Reis, R. M., Branco, M., Caldeira, M. C., Cruz, C. S., Bugalho, M., and Vasconcelos, M. J.: Forests and biodiversity, Climate Change in Portugal, Scenarios, Impacts and Adaptation Measures, edited by: Santos, F. D., Forbes, K., and Moita, R., Gradiva, Lisboa, 369-413, 2002.

Pereira, J. M. C. and Santos, M. T. N.: Fire risk and burnt area mapping in Portugal, Direcção Geral das Florestas, Lisboa, 2003.

Pereira, G., Freitas, S. R., Moraes, E. C., Ferreira, N. J., Shimabukuro, Y. E., Rao, V. B., and Longo, K. M.: Estimating trace gas and aerosol emissions over South America: relationship between fire radiative energy released and aerosol optical depth observations, Atmos. Environ., 43, 6388-6397, 2009a.

Pereira, T. C., Seabra, T., Maciel, H., and Torres, P.: Portuguese na- tional inventory report on greenhouse gases, 1990-2007, Submitted under the United Nations framework convention on climate change and the Kyoto protocol, Agência Portuguesa do Ambiente, $2009 \mathrm{~b}$.

Pio, C. A., Silva, T. P., and Pereira, J. M. C.: Emissões e impacto na atmosfera, in: Incêndios florestais em Portugal: caracterização, impactes e prevenção, edited by: Pereira, J. S., Pereira, J. M. C., Rego, F., Silva, J. M. N., and Silva, T. P., ISAPress, Lisboa, 165-198, 2006.

Pio, C. A., Legrand, M., Alves, C. A., Oliveira, T., Afonso, J., Caseiro, A., Puxbaum, H., Sanchez-Ochoa, A., and Gelencsér, A.: Chemical composition of atmospheric aerosols during the 2003 summer intense forest fire period, Atmos. Environ., 42, 7530 7543, 2008.

Rambal, S.: Hierarchy and productivity of Mediterranean-type ecosystems, in: Terrestrial global productivity, Academic Press, San Diego, 315-344, 2001.

Saglam, B., Kucuk, O., Bilgili, E., Durmaz, B., and Baysal, I.: Estimating fuel biomass of some shrub species (Maquis) in Turkey, Turk. J. Agric. For., 32, 349-356, 2008.

Saltelli, A., Tarantola, S., Campolongo, F., and Ratto, M.: Sensitivity analysis in practice. A guide to assessing scientific models, John Wiley \& Sons Ltd., West Sussex, England, 2004.

Saltelli, A., Annoni, P., Azzini, I., Campolongo, F., Ratto, M., and Tarantola, S.: Variance based sensitivity analysis of model output, Design and estimator for the total sensitivity index, Comput. Phys. Commun., 2009

Salvador, R., Pinol, J., Tarantola, S., and Pla, E.: Global sensitivity analysis and scale effects of a fire propagation model used over Mediterranean shrublands, Ecol. Model., 136, 175-189, 2001.

Sandberg, D. V., Ottmar, R. D., Peterson, J. L., and Core, J.: Wildland fire on ecosystems: effects of fire on air, Gen. Tech. Rep. RMRS-GTR-42-vol. 5. Ogden, UT: US Department of Agriculture, Forest Service, Rocky Mountain Research Station, 79 pp., 2002.

Scholes, R. J., Ward, D. E., and Justice, C. O.: Emissions of trace gases and aerosol particles due to vegetation burning in southern hemisphere Africa, J. Geophys. Res., 101, 23677-23682, 1996.

Schultz, M. G., Heil, A., Hoelzemann, J. J., Spessa, A., Thonicke, K., Goldammer, J. G., Held, A. C., Pereira, J. M. C., and van het Bolscher, M.: Global wildland fire emissions from 1960 to 2000, Global Biogeochem. Cy., 22, GB2002, doi:10.1029/2007GB003031,2008.

Seiler, W. and Crutzen, P. J.: Estimates of gross and net fluxes of carbon between the biosphere and the atmosphere from biomass burning, Climatic Change, 2, 207-247, 1980.

Silva, T. P., Pereira, J. M. C., Paúl, J. C., Santos, M. T. N., and Vasconcelos, M. J. P.: Estimativa de emissões atmosféricas originadas por fogos rurais em Portugal (1990-1999), Silva Lusitana, 14(2), 239-263, 2006.

Simões, S. M.: Expansão ao Alentejo e Algarve de uma curva de acumulação pós-fogo para a biomassa arbustiva, Instituto $\mathrm{Su}-$ perior de Agronomia, Universidade Técnica de Lisboa, Lisboa, 2006.

Sobol', I. M.: Distribution of points in a cube and approximate evaluation of integrals, Zh. Vych. Mat. Mat. Fiz., 7, 784802, U.S.S.R Comput. Maths. Math. Phys., 7, 86112, 1967 (in English, in Russian).

Stamou, N., Kalabokidis, K. D., Konstantinidis, P., Fotiou, S., 
Christodoulou, A., Blioumis, V., Prastacos, P., Diamandakis, M., and Kochilakis, G.: Improving the efficiency of the wildland fire prevention and supression system in Greece, III International Conference on Forest Fire Research, 14th Conference on Fire and Forest Meteorology, Luso, Portugal, 16-20 November, 203221, 1998.

Stephens, S. and Finney, M.: Prescribed fire mortality of Sierra Nevada mixed conifer tree species: effects of crown damage and forest floor combustion, Forest Ecol. Manag., 162(2), 261-271, 2002.

Stohl, A., Berg, T., Burkhart, J. F., Fjæraa, A. M., Forster, C., Herber, A., Hov, Ø., Lunder, C., McMillan, W. W., Oltmans, S., Shiobara, M., Simpson, D., Solberg, S., Stebel, K., Ström, J., Tørseth, K., Treffeisen, R., Virkkunen, K., and Yttri, K. E.: Arctic smoke - record high air pollution levels in the European Arctic due to agricultural fires in Eastern Europe in spring 2006, Atmos. Chem. Phys., 7, 511-534, doi:10.5194/acp-7-511-2007, 2007.

Turquety, S., Hurtmans, D., Hadji-Lazaro, J., Coheur, P.-F., Clerbaux, C., Josset, D., and Tsamalis, C.: Tracking the emission and transport of pollution from wildfires using the IASI CO retrievals: analysis of the summer 2007 Greek fires, Atmos. Chem. Phys., 9, 4897-4913, doi:10.5194/acp-9-4897-2009, 2009.

van der Werf, G. R., Randerson, J. T., Giglio, L., Collatz, G. J., Kasibhatla, P. S., and Arellano Jr., A. F.: Interannual variability in global biomass burning emissions from 1997 to 2004, Atmos. Chem. Phys., 6, 3423-3441, doi:10.5194/acp-6-3423-2006, 2006. van Wesemael, B. and Veer, M.A.C.: Soil organic matter accumulation, litter decomposition and humus forms under mediterraneantype forests in southern Tuscany, Italy, J. Soil Sci., 43, 133-144, 1992.

Vega, J., Fernandes, P., Cuinas, P., Fonturbel, M., Perez, J., and Loureiro, C.: Fire spread analysis of early summer field experiments in shrubland fuel types of northwestern Iberia, Forest Ecol. Manag., 234, S102, doi:10.1016/j.foreco.2006.08.138, 2006.

Vélez, R.: La defensa contra los incendios forestales, Fundamentos y experiencias, Mc- Grawhill, Madrid, Spain, 7.1-7.16, 2000.

Viegas, D. X., Ribeiro, P. R., and Cruz, M. G.: Characterisation of the combustibility of forest fuels, III International Conference on Forest Fire Research, 14th Conference on Fire and Forest Meteorology, Luso, Portugal, 16-20 November, 467-482, 1998.

Wooster, M. J., Perry, G., Zhukov, B., and Oertel, D.: Biomass Burning Emissions Inventories: modelling and remote sensing of fire intensity and biomass combustion rates, in: Spatial Modelling of the Terrestrial Environment, edited by: Kelly R., Drake, N., and Barr, S., 175-196, Wiley, Chichester, UK, 2004.

Wooster, M. J., Roberts, G., Perry, G. L. W., and Kaufman, Y. J.: Retrieval of biomass combustion rates and totals from fire radiative power observations: FRP derivation and calibration relationships between biomass consumption and fire radiative energy release, J. Geophys. Res., 110, D24311, doi:10.1029/2005JD006318, 2005. 